\title{
Os "ribeirinhos" do Pantanal Norte: temporalidades, práticas rurais $e$ cotidiano (1870-1930)
}

\section{Ana Carolina da Silva Borges}

Resumo: O objetivo deste artigo é discutir e analisar a relação estabelecida entre a sociedade e a natureza na extensa área alagável do Pantanal Norte, tendo um interesse maior pelos moradores da beira dos rios São Lourenço e Cuiabá, entre os anos de 1870 a 1930, chamados externamente de "ribeirinhos". Adentraremos no universo pantaneiro que os "ribeirinhos" ajudaram a compor, percebendo suas práticas diárias no contexto das transformações ocorridas em Mato Grosso após o fim da Guerra com o Paraguai (1870) e a reabertura da navegação fluvial, tendo em vista o aumento das relações de troca e comércio locais com as embarcações fluviais, que permitiram a intensificação da exploração dos recursos naturais e a alteração na paisagem pantaneira.

Palavras-chave: "ribeirinhos"; cotidiano; Pantanal.

Abstract: The objective of this paper is to discuss and analyze the relationship between the society and the extensive nature in the wetland in the northern Pantanal, taking a greater interest by the residents along the Rivers São Lourenço and Cuiaba, between the years of 1870 to 1930, known for externally "ribeirinhos". Bogtrotter enters in the universe that the "ribeirinhos" helped to compose, realizing their daily practices in the context of changes in Mato Grosso after the War with Paraguay (1870) and the reopening of river traffic, having in view the growth of the relations of exchange and trade places with the river boats, which led to the intensification in exploitation of natural resources and changed the landscape of the Pantanal.

Keywords: "ribeirinhos"; everyday; Pantanal.

O que observamos atualmente é que o Pantanal tem sido alvo de muitas pesquisas $^{1}$, na qual este ambiente é valorizado, sobretudo, pelos seus aspectos naturais - a diversidade da flora e da fauna e o funcionamento do ciclo das águas. No entanto, a relação dos homens e mulheres que habitavam e habitam a região tem sido sistematicamente silenciada em favor de uma visão idílica sobre meio natural.

\footnotetext{
* Mestre pela Universidade Federal de Mato Grosso. Professora Substituta da Universidade Estadual de Mato Grosso. anaborgeshis@gmail.com

${ }^{1}$ Como exemplo, podemos mencionar os seguintes estudos: DA SILVA, C. J. \& SILVA, J. A., "No ritmo das águas do Pantanal mato-grossense". São Paulo: NUPAUB - Núcleo de Apoio a Pesquisa sobre Populações e Áreas Úmidas Brasileiras, 1995/GALETTI, da S. G., "Nos Confins da Civilização: sertão, fronteira e identidade sobre as representações sobre Mato Grosso". São Paulo, FFLCH/USP, 2000 (Tese de doutorado)./ CASTRO, M. I. \& GALETTI, L. G., Um Histórico dos Usos da Biodiversidade em Mato Grosso. In: CASTRO, C. F. de A, "Diagnóstico do setor florestal em Mato Grosso", Brasília: IBAMA/FUNATURA, 1994.
} 
Buscando contribuir para a compreensão sobre as populações pantaneiras, este artigo dará atenção a uma pequena parcela dos trabalhadores rurais da área alagável, localizada ao longo das margens dos rios São Lourenço e Cuiabá, entre os anos de 1870 a 1930, região esta atualmente conhecida como Pantanal Norte, se atentando principalmente para o estudo dos habitantes denominados de "ribeirinhos".

Este grupo de trabalhadores agrários, segundo aponta a documentação e a bibliografia especializada, podem ser definidos como pequenos agricultores livres que possuíam relativa autonomia em relação às fazendas, aos engenhos e usinas. Os mesmos dedicavam-se à agricultura, como os plantios de milho, criavam animais domésticos e gado, além de praticarem a pesca e a caça; produziam para a sua vivência e também comercializavam seus produtos de diferentes formas de acordo com os diferentes contextos, do qual trataremos aqui o referente aos anos de 1870$1930^{2}$.

A justificativa para tal recorte temporal se dá pelo simples fato de que em 1870 a região em questão passa por algumas transformações com o fim da Guerra do Paraguai e a reabertura da navegação fluvial, fazendo com que o comércio da Província se intensificasse. É a partir de então que o barco a vapor passa a ser cada vez mais utilizado, diminuindo o tempo das viagens que duravam em torno de três ou quatro meses para um mês, e a região é inserida no comércio internacional. Esses fatores contribuíram para a entrada de capitais estrangeiros em Mato Grosso e fez com que os proprietários do Pantanal tivessem maiores lucros e pudessem investir nas fazendas e usinas de produção de açúcar ali existentes, ao mesmo tempo em que as populações fixadas à beira dos rios puderam aumentar consideravelmente as trocas e vendas de produtos caseiros, de animais domésticos e principalmente silvestres, lenha, e de outros artefatos com as embarcações que ali paravam.

Como marco final de nosso recorte temporal, escolhemos o ano de 1930 por expressar mudanças na organização social, política e econômica no estado de Mato Grosso. A começar pelas construções das estradas de ferro (1914) e de rodagem que diminuíam as viagens de um mês para quinze dias ${ }^{3}$. Diante disso as rotas fluviais deixaram de ser a melhor opção para o escoamento da produção agro-pastoril e para a

\footnotetext{
${ }^{2}$ Seria interessante reiterar que ao longo dos anos pesquisados a região estudada era composta por uma diversidade de paisagens (sítios, roças, fazendas de gado, usinas, engenhos de açúcar, colônias indígenas além da paisagem natural) e agentes sociais (negros, índios e brancos que formavam os fazendeiros, donos de usinas e engenhos, agregados, camaradas, índios e ainda os grupos rurais que trataremos que eram os pequenos agricultores rurais denominados de "ribeirinhos"). Cf: BORGES, A. C . da S. "Nas Margens da História: ruralidade e comunidades 'ribeirinhas' no Pantanal Norte (1870-1930)". UFMT, Dissertação de Mestrado, 2008.

${ }^{3}$ Cf: SILVA, E. P., "O cotidiano dos viajantes nos caminhos fluviais de Mato Grosso (1870-1930)". Dissertação de Mestrado, UFMT, 2002.
} 
comercialização de mercadorias em geral. Com o golpe de Getúlio Vargas (1930), quando houve o combate ao coronelismo e a intensificação da política de integração nacional, ocorreu no Pantanal Norte uma gradativa queda da exploração dos recursos naturais (peles de animais silvestres, retirada de lenhas, produções caseiras entre outros). Esses fatos corroboraram para as modificações nas relações estabelecidas entre fazendeiros, usineiros e "ribeirinhos", assim como as relações de poder locais".

Entre as modificações ocorridas no período pós-guerra com o Paraguai, investigaremos as relativas às atividades diárias dos "ribeirinhos" dos ambientes rurais do Pantanal Norte, dando atenção especial as continuidades e descontinuidades na percepção de tempo deste grupo social, e como isso se configurou no cotidiano local. Isto é, percorreremos o "tempo das usinas", o "tempo da navegação a vapor" e conseqüentemente, as alterações que esta temporalidade engendrou na paisagem e espacializações a beira dos rios.

Contudo, a noção de tempo de um determinado grupo social para ser desnudada e apreendida necessita de uma análise que tenha em mente a relevância dos princípios que norteiam as práticas, em torno destas devem ser compreendidas os elementos que as criam, que as provocam, que as fazem emergir e tornarem-se possíveis. Ou seja, o tempo tem a sua função e utilidade no dia-a-dia.

Para o historiador inglês Thompson, um pesquisador deve ter o cuidado em compreender que a reprodução de novas ações cotidianas em virtude de sua articulação com o mercado externo, não deve servir para justificar a hipótese da adoção de uma nova forma de relacionar-se com o tempo em detrimento da forma pré-existente ${ }^{5}$. Mesmo em sociedades industriais, a mudança na percepção de tempo dos trabalhadores é questionada. Segundo Thompson

Entretanto, é improvável que esse impressionismo grosseiro faça avançar a presente investigação: até que ponto, e de que maneira, essa mudança no senso do tempo afetou a disciplina de trabalho, e até que ponto influenciou a percepção interna de tempo dos trabalhadores? Se a transição para a sociedade industrial madura acarretou uma restruturação rigorosa dos hábitos de trabalho- novas disciplinas, novos estímulos, e uma nova natureza humana em que esses estímulos atuassem efetivamente-, até que ponto tudo isso se relaciona com mudanças na notação interna do tempo ${ }^{6}$

Para este historiador a disciplina no trabalho não se configurou enquanto um elemento novo nestes períodos de transformações. Ela já existia. O que modificou foi a

\footnotetext{
${ }^{4}$ Obviamente essas transformações não ocorreram particularmente no ano de 1930, mas este ano surge como um marco significativo para a emergência de todas as mudanças supracitadas.

${ }^{5}$ THOMPSON, E. P., Tempo, disciplina de trabalho e capitalismo industrial. In: "Costumes em Comum: estudos sobre cultura popular tradicional". Fontes - São Paulo: Companhia das Letras, 1998, p. 268-269.

${ }^{6}$ Idem, ibidem, p. 269.
} 
sua importância e, principalmente, os tipos de disciplinas que passaram a ser engendradas a partir de então, assim como as novas leis, os novos valores. São esses aspectos que devem ser pensados no estudo sobre a percepção de tempo.

Achar que entre os grupos ou comunidades "tradicionais" não havia uma organização interna que preconizasse uma ordem, uma divisão de tarefas, é submeter à análise desses trabalhadores a críticas vagas e ausentes de sustentabilidade. Internamente, a noção de tempo contava com regras e lógicas próprias que norteavam e redistribuíam as funções entre os integrantes da comunidade, comumente ligados por laços familiares.

De acordo com Thompson entre os denominados “'povos primitivos' a medição do tempo está diretamente relacionada com os processos familiares nos ciclos dos trabalhos ou das tarefas diárias" 7 . Nesse caso, o tempo não é moeda, as atividades diárias empreendidas por cada trabalhador não obedecem a regras de algum patrão com horários específicos e padronizados, tendo cada minuto, cada segundo vigiado e marcado pelo relógio; pelo contrário, o tempo é controlado pelo próprio trabalhador.

Estamos aqui tratando do que Thompson define como "tempo da natureza", que era praticado entre as "sociedades camponesas", fossem eles agricultores, pescadores, caçadores, extrativistas, entre outros. É a respeito desse tempo que discutiremos nas próximas páginas, nos voltando ao ambiente agrário em que os "ribeirinhos" ajudavam a formar.

\section{A CAÇA: UMA ATIVIDADE LUCRATIVA}

Turmas de caçadores acompanham nas matas durante duas semanas ou um mês, alimentando-se de churrasco de capivara, dias e dias para voltar ao cabo, com um bom carregamento de peles valiosas. E voltam fortes, muitos até curados do amarelão. Por causo do óleo da bicha, afirmam. Os próprios vaqueiros que só extemporaneamente se entregam a caçadas, ainda fazem uma colheita regular de couros ${ }^{8}$.

Estas descrições foram feitas por Manoel Cavalcante Proença, intelectual cuiabano conhecido por ter lecionado em instituições importantes a nível nacional nos anos de 1940, como a Academia Militar das Agulhas Negras; além de publicar obras literárias na década seguinte, descrevendo a cultura mato-grossense, especificamente, caracterizando a região pantaneira. Neste pequeno trecho da obra de Proença nos é revelado não apenas a utilização de uma das atividades desenvolvidas entre os

\footnotetext{
${ }^{7}$ Idem, ibidem, p. 269.

${ }^{8}$ PROENÇA, M. C. de, "No termo de Cuiabá". Rio de Janeiro, MEC/INL, 1958, p. 53.
} 
trabalhadores rurais do Pantanal, mas principalmente, nos trás indícios das mudanças agrárias que estavam acontecendo naquela região. Aponta-nos a intensificação da caça perante a importância econômica dos animais silvestres e seus derivados como matéria prima ao mercado nacional e mundial, possibilitado graças ao aumento das relações de troca e comércio dos moradores locais com as embarcações fluviais.

Esta prática rural, desenvolvida também entre os "ribeirinhos", tornou-se relevante fonte de renda na área em estudo. No trecho, trabalhadores referidos como "caçadores" seriam especializados nesta atividade e despenderiam a maior parte de seu tempo na mata na busca de "peles valiosas". Contudo talvez, o detalhe mais rico e significativo do relato esteja voltado ao apontamento feito a trabalhadores que não se encaixavam como caçadores, os "vaqueiros", que alternavam suas tarefas entre a caça e a "lida" com o gado. Isto é, a caça desempenhava distintas funções entre os trabalhadores rurais do Pantanal indo desde uma atividade esporádica, até uma tarefa diária e dividida em pequenas temporadas.

No entanto, ainda ficam as perguntas: quem eram esses caçadores? Que tipo de funções ou grupos rurais eles compunham? Eram realmente caçadores ou o estudioso Proença se precipitou ao utilizar-se esse termo?

Para responder estas questões teremos que percorrer novamente os indícios deixados pelos documentos descritivos, de cunho etnográfico; já que tabelas dos relatórios dos governantes provinciais e estaduais não davam conta, definitivamente, das práticas e das relações sociais que possibilitavam a exploração de animais silvestres. O trecho do relato feito pelo estrangeiro M. G. Mulhall apresenta indícios,

Foi alívio depois de alguns dias nessas selvas, podermos chegar ao agradável rancho do João Augustin, onde nos recuperamos e nos foram oferecidos refrescos. O pobre homem tem um braço paralisado, resultado de um encontro com uma onça que rasgou os músculos do seu ombro. Ele tem muitas peles de onça, os quais nos vendem por dólares cada ${ }^{9}$.

\footnotetext{
${ }^{9}$ MULHALL, M. G., "Viagem a Mato Grosso". Instituto Histórico e Geográfico de Mato Grosso. Publicações Avulsas no 11, 1998, p. 42. Vale destacar que neste artigo os camaradas podem ser caracterizados como os trabalhadores que com a 'extinção' da escravidão compunham um dos grupos sociais mais desfavorecidos nas relações de trabalho no campo, ocupando um lugar muito próximo ao do trabalho compulsório. Algumas vezes denominados também de "peões", este grupo de trabalhadores rurais realizava trabalhos temporários nas fazendas, usinas e engenhos e estabeleciam uma relação diferenciada da que era conferida aos agregados, tendo em vista que era reduzido o compromisso com os laços de fidelidade com o seu patrão. Aliás, a própria qualificação de "peão" nos possibilita perceber certa dimensão da relação destes com as fazendas, que empregava uma mão-deobra, sobretudo para a lida com o gado. Cf: CORRÊA FILHO, V., "Pantanais mato-grossenses: devassamento e ocupação". Rio de Janeiro: Serviço Gráfico do Instituto Brasileiro de Geografia e Estatística, 1946. (Biblioteca Geográfico Brasileiro. Série A: “Livros”, Publicação, vol. 3), p. 122.
} 
Logo acima, há uma alusão ao "ribeirinho" indicando sua habitação: o rancho na beira do rio. O que mais nos chama atenção neste fragmento de relato, é a venda em dólar da pele de onça. A negociação dessa matéria-prima revela a valorização deste recurso disponível para um mercado estrangeiro, assinalando também a circulação monetária, ainda que não seja possível mensurá-la.

A caça, portanto, passou de uma ação praticada como complementar (utilizada para completar a alimentação, ingredientes de remédios, além de ser espaço de divertimento), para constituir-se como uma atividade lucrativa, que fez com que muitos trabalhadores autônomos se empenhassem na captura de animais silvestres como onças, capivaras, jacarés, ariranhas e uma diversidade de aves. Além dos "ribeirinhos", a caça passou a ser intensificada por outros trabalhadores rurais. Corrêa Filho ${ }^{10}$ observa que,

Entre os empregados das fazendas maiores e das empresas estrangeiras usualmente encontravam-se alguns camaradas contratados para a caça de onças, em especial no Pantanal, onde estes animais representavam uma ameaça constante para as reses. Em algumas fazendas a caça representava uma fonte de lucro adicional, pois a pele de muitos animais era vendida a preços compensadores. ${ }^{11}$

Sobre a comercialização de peles de animais, nas grandes propriedades, destacava-se a importância de um espaço rural e local: o armazém. O viajante norteamericano Roosevelt ${ }^{12}$, no começo do século XX, ao passar pela fazenda Brazil Land and Cattle Company (empresa do Sindicato Farquahar), descreveu que

No armazém se encontravam pilhas de peles de onça, puma, jaguatirica, jaguarundi, jaguar e uma grande pele de lobo vermelho. Eram adquiridas dos vaqueiros e dos índios mansos, por preços de acordo com a cotação de

\footnotetext{
${ }^{10}$ Para melhor entendermos os diversos ambientes e agentes sociais que formaram o espaço pantaneiro, utilizaremos diversas citações do trabalho de Virgílio Corrêa Filho, uma vez que este estudioso desenvolveu importantes trabalhos relativos ao ambiente pantaneiro, tanto referentes aos aspectos geográficos quanto aos históricos. Contudo, apesar de sua grande contribuição para a história social e cultural de Mato Grosso, não podemos deixar de fazer algumas considerações sobre como este pesquisador elaborou sua perspectiva sobre a história da região. Sem deixarmos de apontar, desde já, que esse autor se preocupou em identificar os sinais de "progresso" e "civilização" no "desenvolvimento histórico" do estado. De fato, não é difícil perceber em Corrêa filho o empenho em demonstrar as transformações que estavam levando Mato Grosso a trilhar "os caminhos do progresso", ao destacar a chegada e o papel que aí passaram a desempenhar as ferrovias, os aviões, entre outros. Portanto, assim como os relatos de viagem, mais do que referência bibliográfica o trabalho de Corrêa Filho é também, referência documental.

${ }^{11}$ CORRÊA FILHO, V., op. cit., p. 216.

${ }^{12}$ Theodoro Roosevelt foi um visitante norte-americano que esteve em Mato Grosso na Companhia de Rondon. Nascido em 1858, assumiu o cargo de vice-presidente daquela nação, no ano de 1901, chegando ao cargo de Presidente da República cinco anos depois. Esteve no Brasil, na primeira metade do século XX, como integrante da expedição que explorou as regiões do centro-oeste e Amazonas - Expedição RooseveltRondon - deixando suas impressões de viagem na obra: "Através dos sertões no Brasil". Neste livro, Roosevelt dedicou todo o capítulo IV a viagem que realizou de Corumbá a Cuiabá
} 
cada uma, à medida que iam sendo retiradas. Aos jaguares, vez por outra, matavam cavalos e vacas, mas nunca vitimavam touros. Os pumas preferiam os bezerros. As outras espécies de felinos só de raro em raro apresavam algum torneiro, pois de ordinário davam preferência aos carneiros, leitões e galinhas. Vimos também a pele de um jaguar preto. ${ }^{13}$

Outro aspecto que pode ser verificado em relação a captura de animais silvestres é a sua comercialização desenvolvida por algumas comunidades indígenas ${ }^{14}$, como foi apontado logo acima. Viajantes também referenciavam esta atividade entre os índios tal como fez Bartolomé Bossi ${ }^{15}$, na década de 1860 , quando percorria o território alagável:

A tribo dos Guatós visita nessas alturas ambas orillas do São Lourenço e habita nas suas imediações. É uma tribo inofensiva, que vive da pesca e da caça-. Seu pequeno comércio se limita a algumas peles de tigre e outros animais, que vendem aos viajantes ${ }^{16}$

Nesse sentido, a caça praticada no meio agrário do Pantanal Norte poderia ser desenvolvida por distintos moradores rurais, fossem eles índios, camaradas, "ribeirinhos" ou mesmo agregados ${ }^{17}$. No entanto, esta ação alcançava distintas funções e gastos de tempo de acordo com a importância que a mesma adquiria para cada morador local. A discussão de Thompson sobre a relação entre o "tempo da natureza" e o cumprimento de tarefas é significativa para discutirmos este aspecto. Para o autor,

É possível propor três questões sobre a orientação pelas tarefas. Primeiro, há a interpretação de que é mais humanamente compreensível do que o trabalho de horário marcado. $O$ camponês ou trabalhador parece cuidar do que é uma necessidade. Segundo, na comunidade em que a orientação pelas tarefas é comum parece haver pouca separação entre o "trabalho" e a

\footnotetext{
${ }^{13}$ ROOSEVELT, T., "Nas selvas do Brasil". Tradução de Luiz Guimarães Junior; apresentação de Mario Guimarães Ferri. EdUSP: Itatiaia, 1976, p. 91.

${ }^{14}$ No Pantanal Norte, havia os índios Borôro, Guaná e Guató, que nas primeiras décadas do século seguinte passaram a fazer parte dos trabalhadores rurais, na qual a maioria tornaram-se camaradas.

${ }^{15}$ Bartolomé Bossi foi um marinheiro italiano, que passou uma parte considerável de sua vida na América do Sul. Estava na Argentina quando decidiu viajar para Mato Grosso, em virtude da situação política instável daquele país. Chegou à província no princípio dos anos de 1860 , tendo todas as despesas pagas pelo então presidente da província Herculino Ferreira Pena.

${ }^{16}$ BOSSI, B., "Viagem pintorescco por los rios Paraná, Paraguay, San Lourenzo, Cuyabá y el Arino del grande Amazonas com la descripcion de la Província de Mato Grosso bajo su aspecto fisico, geográfico, mineralógico u sus producciones naturales". Paris, Dupray de la Mahérie, 1862, p. 48.

${ }^{17}$ Os agregados eram aqueles grupos de trabalhadores que normalmente residiam em um pedaço de terra cedido pelo patrão, onde podiam morar, estes vivendo com suas famílias, possuíam uma relação de maior proximidade com o fazendeiro, com acesso contínuo à sua residência e liberdade para desenvolver algumas atividades autônomas, como a agricultura e a criação de animais, garantindo, desse modo, a continuidade de sua reprodução social nas fazendas. CORRÊA FILHO, V., idem, ibdem, p. 122/ LUCíDIO, J. A. B., “A ocupação do Planalto Sul de Mato Grosso (1830-1870)". Niterói: Universidade Federal de Fluminense, Dissertação de Mestrado, 1991, p. 62.
} 
"vida". As relações sociais e o trabalho são misturados- o dia de trabalho se prolonga ou se contrai segundo a tarefa- e não há nada grande senso de conflito entre o trabalho e "passar do dia". Terceiro, aos homens acostumados com o trabalho marcado pelo relógio, essa atitude para com o trabalho parece perdulária e carente de urgência. ${ }^{18}$

A interpretação de que o tempo orientado por tarefas "é mais humanamente compreensível", se deve ao fato de que é um tempo norteado por funções e controlado individualmente. No "tempo da natureza" existe uma flexibilidade com o horário dos afazeres diários, pouca exigência sobre um número de excedentes e a viabilidade da diversificação dos serviços realizados. Essas características nos levam a refletir a elasticidade que esta temporalidade permite no que se refere as modificações que giram ao redor do habitus ${ }^{19}$ familiar. E mais, a ausência de uma fronteira específica e rígida entre o "trabalho" e a "vida", nos leva a defender a hipótese que as ações diárias não se constituíam enquanto uma obrigação, um compromisso alienado tendo que ser cumprido a qualquer custo pelos trabalhadores locais. Pelo contrário, a "vida" assumia um caráter simbiótico entre o "prazer" e tarefas cotidianas.

O muxirum é um exemplo claro disso, estando este atrelado às novas relações ou trocas de experiências que começavam a ser interiorizadas. Trabalhos prestados em conjunto para o bem-estar de todos os envolvidos, que finalizavam seus dias com orações e festividades locais.

Podemos, contudo, fazer algumas colocações a esse respeito. Vejamos o caso da caça. Normalmente ela era realizada em parcerias, em bando, em turmas ${ }^{20}$. Moradores que se "embreavam" na mata para a captura de animais escolhidos, levando dias, semanas ou meses. Ao retornarem os trabalhadores se ocupavam da venda dos produtos da caça e, posteriormente, poderiam passar a dedicar-se a outras atividades.

A caça era, portanto, praticada em mutirão. De fato, isso pode ser explicado tendo em vista que se antes da reabertura fluvial ela era desenvolvida como uma tarefa de "descontração", para complemento alimentar ou na intenção de espantar animais que invadiam a horta, roça ou que matavam o gado, as galinhas, dentre outras situações. Após 1870, a caça passa então a ser cada vez mais utilizada na medida em que seu valor agora adquiria caráter monetário. No entanto, a forma de ser desencadeada não se alterou, ela continuava a ser perpetuada em mutirão. Para os denominados "caçadores", o seu tempo era marcado por esta tarefa temporariamente

\footnotetext{
${ }^{18}$ THOMPSON, E. P., op. cit., p. 271-272.

${ }^{19}$ BOURDIEU, P., "Sociologia: esboço de uma teoria da prática”. São Paulo: Ática, 1995, p. 60-61.

${ }^{20}$ PROENÇA, M. C. de, op. cit., p. 162.
} 
ou não, até onde cada um destes determinasse que devesse e tinha condições de realizá-la. Assim é o "tempo da natureza", flexível, no qual as atividades diárias estavam vinculadas ao meio natural.

Tempo este facilmente de ser identificado entre os "ribeirinhos" e entre vários povos indígenas. Mas quando nos referimos aos camaradas que desempenhavam suas funções, conforme as ordens dadas pelos grandes proprietários rurais, a situação se modificava. O tempo não estava sob um controle individual, mas sim sob o domínio de seus "senhores", cujo "labuta" diária, era marcada por uma maratona de obrigações rigidamente pré-determinadas e vigiadas. Nas usinas, assim era marcado o tempo de trabalho:

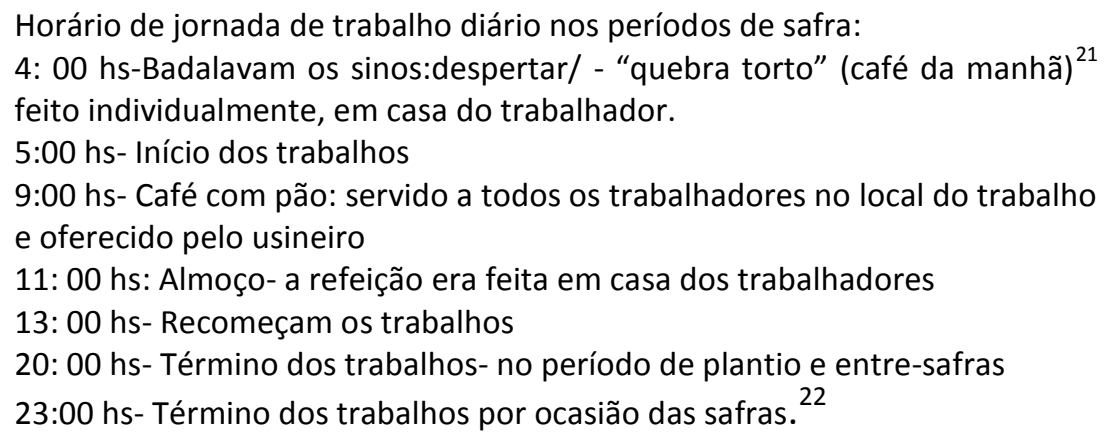

Siqueira nos revela que as atividades obedeciam a uma regularidade diária muito bem estruturada. A disciplina metódica, ordenada, monótona e, principalmente repetitiva, isto é, nestas grandes propriedades do Pantanal Norte não era desenvolvido o "tempo da natureza", mas sim o "tempo industrial". Tempo este também identificado como o tempo do "progresso", das "máquinas", que computa uma repetição contínua de ações mesmo que desenvolvidas em um ambiente agrário. "Trabalho" e "diversão" são duas noções bem distintas e separadas entre os empregados, em que a produtividade cronometrada minimizava o trabalhador a possibilidade de atualizar as práticas costumeiras frente a um novo contexto.

Ainda sobre a jornada de trabalho, realizada nas grandes propriedades das usinas de açúcar no Pantanal, podemos identificar outro elemento: a utilização do sino. Instrumento usado para acordar os trabalhadores rurais, o sino pode ser considerado como um bom artifício no que tange ao controle do tempo e do trabalho,

\footnotetext{
${ }^{21}$ Comida típica local que diz respeito a mistura de arroz, farinha, ovos e carne.

${ }^{22}$ SIQUEIRA, E. M., “A ocupação pioneira da região do rio Cuiabá abaixo”. Cuiabá: Instituto Histórico e Geográfico de Mato Grosso. 1997. (Publicações avulsas, no 01), p. 70 e 71./ GAETA, L. H., "Vozes no silêncio: subordinação, resistência e trabalho em Mato Grosso (1888-1930)". Cuiabá, UFMT-EDUFMAT, 1995. /PÓVOAS, L.V., “O ciclo de açúcar e a política de Mato Grosso”. Cuiabá: IHGMT e Academia Matogrossense de Letras, 1983.
} 
pois "o som era muito mais eficaz que a visão" ${ }^{23}$, seu efeito era satisfatório, pois seu raio de ação não atingia a um trabalhador mas sim a todos, não prescrevendo a presença física de algum patrão.

Contudo, nas fazendas nas quais os trabalhadores rurais tinham suas obrigações direcionadas para a "lida" com o gado e com a mata fechada o tempo não era marcado de forma tão rigorosa. Vejamos outro trecho do relato do viajante Roosevelt, que nos trás vestígios sobre o tipo de trabalho desenvolvido nas fazendas:

Às seis da manhã, cada um de nós partiu montado num belo animal. O dia estava carrancudo. Trazíamos conosco uma dúzia de cães, porém somente um ou dois eram de valor. Três ou quatro vaqueiros nos acompanharam; eram homens de sangue indígena, que em outras partes do Brasil se diriam peões ou caboclos, mas que ali eram chamados de "camaradas". Foram naturalmente escolhidos entre aqueles que entendiam de caçadas e cada um trazia uma comprida zagaia, um tanto pesada e rústica. ${ }^{24}$

Assim, estes camaradas tinham uma variedade de ações nas propriedades que eram compridas conforme as ordens dadas pelos seus "senhores". Poderiam dedicar-se temporariamente a ações rurais mais específicas, ou diversificálas ao longo do dia em virtude da necessidade dos proprietários.

Neste caso, a caça enquanto prática estava carregada de elementos do "tempo da natureza", ou seja, não seguia uma repetição de ações diárias, tendo um caráter oposto, já que suas atitudes decorriam de acordo com os lugares onde se encontravam os animais, em que eram empreendidas inúmeras estratégias no que toca às variações ambientais, alimentação e reprodução dos "bichos" a serem apanhados. Não havia um horário fixo ditando cada passo a ser traçado no transcorrer do dia e, especialmente, esta atividade ao ser desenvolvida poderia adquirir um significado de "descontração" e "prazer".

Contudo, não sejamos ingênuos, pois a caça entre os camaradas só era permitida na medida em que os recursos naturais provindos desta prática rural fossem negociados com os proprietários das fazendas ou vendidos em suas propriedades. Eram estes, que escolhiam as peles e penas das espécies de animais a serem capturados e que faziam as transações econômicas internamente, ocupando lugar de "intermediários". Isto é, o controle, revestido com novas ferramentas, estava em fluxo contínuo, demonstrando que mesmo a distância, os "senhores" comandavam as condutas de seus "camaradas".

\footnotetext{
${ }^{23}$ THOMPSON, E. P., op. cit. p. 275.

${ }^{24}$ ROOSEVELT, E., op. cit., p. 80.
} 
Percebe-se então, que a reabertura do comércio com a bacia do Prata provocou um redimensionamento nas atividades rurais desenvolvida no Pantanal Norte, e a conseqüente mudança do intercâmbio dos homens, mulheres e crianças entre si e com a natureza. Resta sabermos por que esta prática tornou-se tão significativa na região alagável.

\title{
O COMÉRCIO EXTERIOR: CONSIDERAÇÕES SOBRE AS MERCADORIAS EXPORTADAS
}

No que toca ao período pós-guerra com o Paraguai, L. S. Corrêa ${ }^{25}$ salienta que as relações das comunidades pantaneiras, com o seu meio não havia, até então, ocasionado tantas alterações no ambiente. Com a intensificação do comércio fluvial, a caça passa a ser feita em larga escala e as peles, penas e couros de animais silvestres passaram a ser ainda mais procurados para a comercialização. Mas segundo Côrrea Filho a exportação da pele de alguns animais das florestas de Mato Grosso já acontecia anos antes, se estendendo até as três primeiras décadas do século seguinte,

\begin{abstract}
Por volta de 1844-1845 já eram exportadas de Cuiabá peles de veados e de onças através dos tropeiros que demandavam ao Rio de Janeiro [...]. No ano de 1880, de acordo com a Coletoria Provincial de Corumbá, uma pele de onça pintada era negociada no porto por Rs. $10 \$ 000$. E, meio século depois ainda figurava nas tabelas de exportação do Estado de Mato Grosso peles de onças, de outros animais silvestres e penas de garças. ${ }^{26}$
\end{abstract}

A partir de 1870, essas matérias-primas, fruto da captura de animais silvestres, adentraram no mercado industrial tornando-se mais valorizados e viáveis economicamente, porque passaram os trabalhadores rurais a explorarem estes recursos naturais em maior quantidade. Ao chegarem aos grandes centros industriais, serviam para a fabricação de bolsas, cintos, chapéus, sapatos e demais acessórios. Muitas dessas negociações abasteciam as indústrias exteriores, entre elas as fábricas americanas e inglesas, que eram as maiores do mundo. Como bem salienta L. S. Corrêa:

Depois da guerra mundial de 1914-1918, em conseqüência da paralisação do movimento de capitais, nos mercados europeus, os capitalistas tiveram as suas vistas voltadas para o lado dos couros nos mercados mundiais. Devido a isso organizaram-se três sociedade formidáveis para a exploração em toda a parte do comércio de couros, abrindo armazéns e depósitos

\footnotetext{
${ }^{25}$ CORRÊA, L. S., “A fronteira na história regional: o sul de mato grosso (1870-1920)”. São Paulo: USPFFLCH, 1997. (Tese de doutorado), p. 31.

${ }^{26}$ CORRÊA, V., op. cit., p. 31.
} 
espaçosos nas principais praças, para tal fim. / Por acordo das três enormes sociedades, foi organizado em 1921, o truste geral para o comércio deste produto de origem animal nos principais mercados de compra e venda deste artigo. / Londres e Nova-York constituem os principais mercados para o negócio de couros de diferentes espécies. Assim Londres é o maior mercado, maior centro mundial para negócios de couros vacuns secos; e Nova-York para os couros e peles de animais silvestres ... Essas sociedades fixaram a taxa, o preço para a compra de couros vacuns secos, na cidade de Londres, para os seus agentes espalhados por toda a parte, da seguinte maneira: Couros vacuns secos a $5.1 / 2$ pences; e para as peles de animais silvestres no mercado de Nova-York, fixaram diversas taxas, tomando por base a pele de capivara, que é exportada em grande quantidade, no Rio da Prata, para o fabrico de peles finas, para a indústria de luvas, principalmente, e outras manufaturas semelhantes. / Desse modo: pele de primeira, maior, com 1.20 cents, unidade \$1.75. / Devido ao cambio baixo que temos e, calculando os preços pagos na praça de Corumbá, pelas taxas dadas para os mesmos agentes compradores do truste, encontramos o lucro fabuloso de 40 a 50 \% líquidos, lucro esse que representa um assalto criminoso á economia da Nação Brasileira ${ }^{27}$.

Os produtos destas ações rurais - a caça de animais silvestres - passaram a refletir sua relevância econômica através dos quadros das mercadorias exportadas por Mato Grosso:

TABELA I

Exportações dos principais produtos de Mato Grosso (1908-1911)

\begin{tabular}{|l|l|l|l|l|}
\hline Produtos & 1908 & 1909 & 1910 & 1911 \\
\hline Ipecacuanha & $19: 763 \$ 400$ & $8: 334 \$ 400$ & $10: 663 \$ 800$ & $9: 354 \$ 800$ \\
\hline Erva Mate & $290: 000 \$ 000$ & $291: 493 \$ 920$ & $303: 026 \$ 469$ & $320: 498 \$ 800$ \\
\hline Animais vivos & $49: 113 \$ 000$ & $178: 187 \$ 500$ & $144: 360 \$ 000$ & $99: 993 \$ 000$ \\
\hline Peles & $60: 691 \$ 585$ & $83: 590 \$ 080$ & $95: 791 \$ 011$ & $76: 708 \$ 178$ \\
\hline Outros produtos animais & $27: 599 \$ 747$ & $36: 602 \$ 700$ & $36: 997 \$ 208$ & $50: 263 \$ 418$ \\
\hline Totais & $447: 167 \$ 732$ & $598: 208 \$ 600$ & $590: 838 \$ 488$ & $556: 809 \$ 196$ \\
\hline
\end{tabular}

Fonte: Mensagem. Joaquim Augusto da Costa Marques, 1912. In: CORRÊA, L. S. Op. cit., 1997, p. 64.

Esta tabela faz menção aos "animais vivos", cuja exportação algumas vezes superava as de pele e de "outros produtos animais" indicando seu espaço econômico no estado. Estes "animais vivos" correspondiam principalmente à criação bovina, atividade que ocupava extensas faixas de terras nas fazendas espalhadas por Mato Grosso abrangendo, sobretudo, a região sul do estado, mas também fazia referência à criação de cavalos, concentrada, principalmente, na região de Mimoso - Pantanal ${ }^{28}$.

\footnotetext{
27"Comércio-Trust para o Couro Vacum-Gado-Coco de Babassu-Corumbá-Coxim" e os problemas para serem resolvidos. Trechos de um relatório apresentado pelo Delegado Comercial do C.M. de S. Paulo em Mato Grosso, Sr. K. Seba, à Diretoria do mesmo C.M.S.PÁG. In: ANUÁRIO PROPAGANDISTA "SUL DO BRASIL". Vulgarização Econômica e Curiosidades. Publicidade Comercial, $6^{\circ}$ ano, Curitiba, 1935, p. 8-9. In: CORRÊA, L. S., “A fronteira na história regional: o sul de mato grosso (1870-1920)". Tese de doutorado. São Paulo, USFFLCH, 1997, p. 218-219.

${ }^{28}$ SILVA, C. J. da \& SILVA, J. A. F., op. cit.
} 
Por meio dos dados expostos logo acima, é possível perceber que apenas no começo do século XX cresce a importância dos produtos da caça nas tabelas oficiais de exportação e, conseqüentemente, na arrecadação dos cofres públicos. No ano de 1908 a exportação de peles supera a de "animais vivos". Embora nos anos seguintes esta relação se inverta, a exportação de peles, entre 1908 e 1910 aumentou praticamente $58 \%$.

Contudo, o que este documento nos aponta de mais significativo é a exploração da erva-mate feita em larga escala e responsável, na maioria das vezes - de acordo com os anos supracitados - por mais da metade das exportações de Mato Grosso. Esse fato pode ser mais bem compreendido através da tabela abaixo, que montamos com base nos dados colhidos.

TABELA II

Percentual dos produtos em relação ao total das exportações de Mato Grosso (1908-1911)

\begin{tabular}{|c|c|c|c|c|}
\hline Produtos & 1908 & 1909 & 1910 & 1911 \\
\hline Ipecacuanha & $4 \%$ & $1 \%$ & $2 \%$ & $2 \%$ \\
\hline Erva Mate & $65 \%$ & $49 \%$ & $51 \%$ & $58 \%$ \\
\hline Animais vivos & $11 \%$ & $30 \%$ & $24 \%$ & $18 \%$ \\
\hline Peles & $14 \%$ & $14 \%$ & $16 \%$ & $14 \%$ \\
\hline Outros produtos animais & $6 \%$ & $6 \%$ & $6 \%$ & $9 \%$ \\
\hline
\end{tabular}

Fonte: Elaborada a partir dos dados da Tabela I. Mensagem. Joaquim Augusto da Costa Marques, 1912. In: CORRÊA, L. S., op. cit., 1997, p. 64.

Nesta tabela nos chama atenção os movimentos ao longo de cinco anos do valor nominal das exportações e, principalmente, sua importância no valor total das exportações. O caso da erva-mate é significativo uma vez que nos é indicado na Tabela I um aumento gradual no volume exportado que era inversamente proporcional, especialmente, nos dois anos seguintes à sua participação no valor total. Já em relação aos produtos que tiveram oscilações em suas exportações, não poderíamos deixar de mencionar os "animais vivos" que alcançaram um crescimento anual aproximadamente $272 \%$ em 1909 , e no ano seguinte apresentaram um quadro diferente, tendo em vista a queda em mais da metade de seu porcentual de exportação, o que não significa necessariamente a diminuição do volume exportado, já que uma oscilação dos preços também poderia causar esta queda.

Outro ponto a ser enfatizado é a variedade dos produtos explorados em Mato Grosso, demonstrando um leque de potencialidades locais e lucrativas. Esse fato se deve as florestas do Cerrado, da Amazônia e do Pantanal que serviam como verdadeiras "fábricas e depósitos naturais" de recursos necessários para a produção industrial. 
Todavia, a criação bovina e seus derivados, desde o final do século XIX passaram a ter índices de exportação cada vez mais significativos.

TABELA III

Imposto sobre os produtos exportados de Mato Grosso (1885)

\begin{tabular}{|l|l|l|}
\hline Qualidade & \multicolumn{1}{l|}{ Valor Official } & \multicolumn{1}{l|}{ Imposto } \\
\hline Assucar, café, carne secca, crina de animaes, fumo e graxa & $2: 084 \$ 380$ & $208 \$ 438$ \\
\hline Cal de pedra & $4: 072 \$ 000$ & $203 \$ 600$ \\
\hline Caldo de carne & $43: 200 \$ 000$ & $4: 320 \$ 000$ \\
\hline Couros & $141: 290 \$ 000$ & $14: 129 \$ 000$ \\
\hline Chifres & $2: 460 \$ 000$ & $246 \$ 000$ \\
\hline Herva matte & $337: 083 \$ 000$ & $16: 854 \$ 150$ \\
\hline Ipecacuanha & $43: 739 \$ 500$ & $4: 373 \$ 950$ \\
\hline Gado vaccum & $66: 036 \$ 000$ & $11: 006 \$ 000$ \\
\hline TOTAL & $639: 964 \$ 880$ & $51: 341 \$ 138$ \\
\hline
\end{tabular}

Fonte: Relatório de presidente de província, na 1ㅇsessão, da 26 Legislatura, apresentado pelo Exm. Dr. Joaquim Galdino Pimentel, no dia 12 de Julho de 1886 , Manuscrito, p. 90.

O interessante neste quadro é que ele nos trás os produtos com seu valor oficial e, simultaneamente, os impostos cobrados. Isso, obviamente nos possibilita apreender quais são as atividades mais oneradas em Mato Grosso, em virtude das taxas de exportação, que seriam os fazendeiros, usineiros e os agricultores que cultivavam o fumo, além dos responsáveis pela exploração da ipecacuanha. Todos estes grupos econômicos pagavam impostos para os cofres públicos que giravam em torno de $10 \%$, com exceção da tributação cobrada sobre o "gado vacum" que era a mais alta, em torno de $17 \%$. Esta situação era bem diferente, da que era apresentada pelos cultivadores da erva-mate, que apesar de ser o item mais exportado, era também a que tinha o imposto mais baixo - 5\%- acompanhada de "cal de pedra". Para que isso fique mais claro, optamos por acrescentar na mesma tabela o valor da tributação, como segue abaixo:

TABELA IV

Tributação sobre os produtos exportados ( Mato Grosso, 1885)

\begin{tabular}{|l|l|l|l|}
\hline \multirow{2}{*}{$\begin{array}{l}\text { Qualidade } \\
\text { Assucar, café, carne secca, crina de } \\
\text { animaes, fumo e graxa }\end{array}$} & $2: 084 \$ 380$ & $208 \$ 438$ & $10 \%$ \\
\hline Cal de pedra & $4: 072 \$ 000$ & $203 \$ 600$ & $5 \%$ \\
\hline Caldo de carne & $43: 200 \$ 000$ & $4: 320 \$ 000$ & $10 \%$ \\
\hline Couros & $141: 290 \$ 000$ & $14: 129 \$ 000$ & $10 \%$ \\
\hline Chifres & $2: 460 \$ 000$ & $246 \$ 000$ & $10 \%$ \\
\hline Herva matte & $337: 083 \$ 000$ & $16: 854 \$ 150$ & $5 \%$ \\
\hline Ipecacuanha & $43: 739 \$ 500$ & $4: 373 \$ 950$ & $10 \%$ \\
\hline Gado vaccum & $66: 036 \$ 000$ & $11: 006 \$ 000$ & $17 \%$ \\
\hline TOTAL & $639: 964 \$ 880$ & $51: 341 \$ 138$ & $8 \%$ \\
\hline
\end{tabular}


Neste quadro entre as informações expostas, torna-se pertinente ressaltar que mesmo que o valor oficial das exportações da erva-mate fosse mais que o dobro das oferecidas pelas de couros, o pagamento dos impostos sobre este produto minimizava essa diferença, na medida em que a tributação sobre os couros é o dobro da cobrada sobre a erva-mate.

Um gráfico possibilita perceber que embora, isoladamente, a erva mate gere maior arrecadação do que outros produtos, a soma do item "gado vacum" com os subprodutos bovinos supera a erva mate no valor tributado:

GRÁFICO I

Valor tributado da exportação do gado e seus derivados e da erva mate (valores nominais em réis e percentuais)

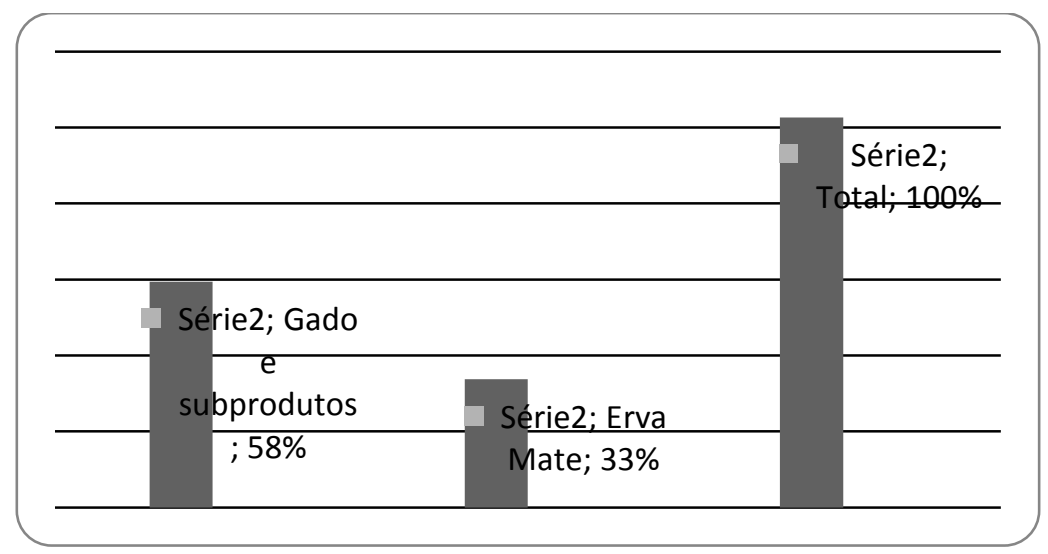

Em relação as exportação de produtos silvestres a tabela abaixo identifica algumas espécies:

TABELA V

Exportações de produtos silvestres de Mato Grosso (em 1920)

\begin{tabular}{|l|l|l|l|l|}
\hline \multicolumn{4}{|c|}{ P/Outros Estadlos } & \multicolumn{2}{l|}{ P/ o Extrangeiro } \\
\hline Produtos & Quantidade & Preço & Quantidade & Preço \\
\hline Couros de onça c/cabeça & 10 & $600 \$ 000$ & 37 & $1: 460 \$ 000$ \\
\hline Couros de onça s/cabeça & 5 & $200 \$ 000$ & 70 & $2: 170 \$ 000$ \\
\hline Couros de veado & 739 & $3: 395 \$ 000$ & & \\
\hline Couros de lontra & & & 3 & $30 \$ 000$ \\
\hline Casca de tartaruga & & & 8 & $30 \$ 000$ \\
\hline Pennas de garça & 16.000 & $9: 600 \$ 000$ & 15.020 & $9: 012 \$ 000$ \\
\hline Pelles diversas & 75 & $377 \$ 000$ & 118 & $240 \$ 000$ \\
\hline
\end{tabular}

Fonte: Mensagem de presidente de estado de Mato Grosso, dirigida á Assembléia Legislativa, ao instalar-se a sua sessão ordinária da 12a Legislatura, feita pelo Dr. Francisco de Aquino Corrêa, Bispo de Prusiade, 7 de Setembro de 1921.

Este documento nos fornece sinais de que a exploração de animais silvestres e a venda de peles, penas entre outros, tinham uma lógica comercial voltada para o mercado estrangeiro, nos permitindo, paralelamente, entender os derivados de cada espécie que agregava valor econômico. 
Seguindo as indicações da tabela, vislumbramos os produtos mais propícios a ficarem ou não no país. No que se refere aos couros de onça, a quantidade destinada ao mercado estrangeiro é sete vezes maior que a destinada para outros estados. Já os couros de lontra e casca da tartaruga têm como destino certo o mercado internacional. As peles de outros animais silvestres têm um porcentual de $60 \%$ maior para o mercado externo que o nacional. A não indicação da exportação para outros países dos couros de veado pode indicar o baixo valor de mercado deste artigo no exterior.

Contudo, sabemos que as espécies de animais silvestres apresentadas na tabela poderiam ser encontradas em todo o território mato-grossense. Entretanto, a possibilidade desses produtos serem oriundos da região pantaneira estaria ligada não apenas a reabertura fluvial, mas sim as novas relações econômicas que passaram a ser perpetuadas a partir de então, viabilizando, inclusive o aumento populacional nestas áreas úmidas ${ }^{29}$.

Outro fator apontado por este documento é a relevância das penas de garça que disparava como uma das mais procuradas e exploradas de Mato Grosso, cujo valor mercantil caminhava em mão dupla, pois era estimado internacionalmente e nacionalmente. Á esse respeito veremos que de acordo com a tabela apresentada logo abaixo, as penas de garça tiveram um salto em sua exploração nos anos de 1920, em que a intensificação dessa atividade refletirá diretamente nas tabelas de exportação.

TABELA VI

Estatística de Exportação de Penas de Garça (1916-1925)

\begin{tabular}{|l|l|l|l|}
\hline Annos & Quantidade & \multicolumn{2}{l|}{ Valor Official } \\
\hline 1916 & 26.996 & $11: 521.700$ & $1: 728.255$ \\
\hline 1917 & 18.197 & $10: 918.200$ & $1: 637.800$ \\
\hline 1918 & 19.540 & $11: 724.000$ & $1: 758.600$ \\
\hline 1919 & 111 (sic) & $66: 835.800$ & $10: 025.370$ \\
\hline 1920 & 31.020 & $18: 612.000$ & $2: 791.000$ \\
\hline 1921 & 27.112 & $22: 267.200$ & $3: 340.080$ \\
\hline 1922 & 22.804 & $15: 537.500$ & $3: 330.625$ \\
\hline 1923 & 63.727 & $33: 376.200$ & $5: 006.430$ \\
\hline 1924 & 211.775 & $134: 159.735$ & $20: 123.960$ \\
\hline 1925 & 250.952 & $149: 541.675$ & $22: 431.250$ \\
\hline
\end{tabular}

Fonte: CORRÊA, M. Mensagem á Assembléia Legislativa, lida na abertura da sua 1a sessão ordinária da 14ạ legislatura. Cuiabá, 13 de Maio de 1927.

De acordo com este documento a quantidade de penas de garças exportadas cresceu em torno de $1000 \%$, em menos de dez anos. O que nos chama atenção é que no ano de 1922 a 1924 ocorreu um salto exorbitante em mais de $900 \%$, ou seja, não foi

\footnotetext{
${ }^{29}$ SIQUEIRA. E. M., Panorama Geral do Rio Cuiabá abaixo: século XIX e XX. In: “Ocupação pioneira do Rio Cuiabá abaixo. Cuiabá: Instituto Histórico e Geográfico de Mato Grosso". 1997 (Publicações avulsas, no 1), p. 63-83.
} 
um crescimento regular tendo em vista que houve alguns anos que sua exploração apresentou queda (1917, 1918, 1921 e 1922).

Percebe-se também, o quanto o estado lucrou com a saída desta matéria-prima para outros países, já que seus direitos aumentaram em mais $2000 \%$, levando em conta que estamos diante de um documento oficial, que preconizava um controle sobre as atividades econômicas. A caça e os comércios ilegais que escapavam das cobranças de impostos, se possíveis fossem contabilizá-los elevariam os números da exportação.

Nesse sentido, estamos vendo aqui a importância econômica da realização da caça para o estado de Mato Grosso, e para os grupos que dela se utilizavam. Alguns fatores já foram notados em relação a esta atividade: a primeira era a de que parte dos produtos silvestres que saía da província ou do estado possivelmente seria da região em estudo, isto é o Pantanal Norte; o segundo se refere ao simples fato de esta atividade cresceu aos poucos, emergindo, sobretudo, a partir de 1870 e tendo seu apogeu nas primeiras décadas do século seguinte; e o terceiro foi que a captura de animais silvestres atendia, em sua grande parte, ao mercado internacional.

\section{ENTRE A CASA, O QUINTAL E O RIO: A INTENSIFICAÇÃO DE OUTRAS PRÁTICAS}

É possível vislumbrar que não só a caça, mas também outras práticas começaram a ser cada vez mais realizadas pelos "ribeirinhos" no período em questão. Produtos caseiros como doces e requeijão, também foram frutos de atividades intensificadas no Pantanal Norte. Tal como a caça, estes alimentos que provinham dos trabalhadores rurais poderiam ser negociados com comerciantes dos caminhos fluviais, além de, obviamente, serem consumidas internamente.

Dentre as embarcações que navegavam os rios, existiam variações - de tamanho, porte e função ou utilidade. Os que nos chamaram maior atenção foram àquelas consideradas mais "luxuosas" responsáveis, sobretudo, pelo transporte de passageiros, uma vez que apresentavam em suas refeições diárias cardápios diversos que estivessem de acordo com o padrão financeiro de seus passageiros ${ }^{30}$. Entre os alimentos servidos, possivelmente uma parte significativa procediam da região pantaneira, tendo em vista que esses transportes fluviais eram reabastecidos por produtos caseiros, nos portos locais das grandes propriedades agrárias, e de lá

\footnotetext{
${ }^{30}$ Cf: SILVA, E. P., op. cit.
} 
seguiam rumo a Corumbá e/ou outros países vizinhos platinos. Isso pode ser detectado através dos sinais deixados pelos tipos de comida servidos ao longo das viagens. Segundo o viajante Steinen:

Às dez é servido o almoço: sopa, puchero (cozido de carne de vaca com repolhos e batatas), excelente pirão ( é a farinha cozida com caldo), dois pratos de carne; também se serve, em substituição ao primeiro, o apreciado bacalhau. Compota, doces de queijos de Edam. Vinho tinto a vontade (aqui era agradável e café). As três e trinta horas uma xícara de café. Às cinco horas temos um prato a mais do que no almoço, depois ainda um cálice de Cherry ou Porto $[\ldots]^{31}$.

Queijos $^{32}$, rapaduras $^{33}$, doce de goiaba ${ }^{34}$ e bolachas ${ }^{35}$; bem como outros alimentos que não foram referenciados, eram oferecidos para os passageiros durante essas viagens. Porém, além da produção caseira a criação de animais também se inseriu entre as atividades intensificadas. Frangos, galinhas, porcos e o gado estavam incluídos entre os animais provindos do meio rural que eram negociados e renegociados com as embarcações fluviais. O viajante Mulhall faz a seguinte observação, quando estava de passagem no Pantanal Norte:

\begin{abstract}
Em uma manhã chegamos num rancho localizado num istmo de terra que estende rio adentro, onde observamos algumas galinhas; o dono, um bom humorado velhinho, com um chapéu de palha e calças de linho, nos vendeu algumas galinhas por poucos dólares. As lanchas têm lugares certos e regulares onde param para se abastecer de lenha e comprar galinhas. No mesmo dia paramos à noite num rancho semelhante daquele já mencionado, e vimos um brasileiro gêmeo daquele de manhã. Um dos passageiros the perguntou se ele tinha galinhas para vender, e ele replicou "não, está manhã vocês levaram todas as que eu tinha". Era o mesmo velhinho e o mesmo rancho; só que desta vez ele saiu pelos fundos em vez da frente. Viajamos não sei quantas milhas pelas curvas do rio, e o capitão chegou a recolher um novo estoque de lenha; estávamos somente 50 metros, por terra, do lugar por onde passamos pela manhã. ${ }^{36}$
\end{abstract}

\footnotetext{
${ }^{31}$ STEINEN, K. v. de, “O Brasil Central: expedição em 1884 para a exploração do rio Xingu”. Trad. Catarina Baratz Canbrava. São Paulo, Nacional, 1942, p. 55.

32 NEDHIR-UFMT, Cuiabá-MT. Rolo 2, Guia de Exportação(1892-94), Corumbá, 8 de Fevereiro, 1892. Despachado por Antonio Joaquim da Rocha o que abaixo se declara para Assunção, no Vapor "Humaitá", 1 Caixa contendo 63 Kls de queijos.

${ }^{33}$ NEDHIR-UFMT, Cuiabá-MT. Rolo 2, Guia de Exportação(1892-94), Corumbá, 11 de Janeiro de 1892. Despachado por Burges o que abaixo se declara para o Paraguai, no Vapor "Humaitá" de produção Nacional Livre, contendo 10 caixas com 1.100 rapaduras.

${ }^{34}$ NEDHIR-UFMT, Cuiabá-MT. Rolo 2, Guia de Exportação(1892-94), Corumbá, 16 de março de 1892. Despachado por CAVASSA \& CIA vapor, para Assunção República do Paraguai, 1 caixão contendo setenta e cinco kls de doce de goiaba.

35 NEDHIR-UFMT, Cuiabá-MT. Rolo 2, Guia de Exportação(1892-94), Corumbá, 19 de Fevereiro. Despachado por CAVASSA \& CIA no vapor "Diamantino", para Montevidéu República Oriental do Uruguai, contendo 24 marradas e 133 bolachas pesando $990 \mathrm{kls}$.

${ }^{36}$ MULHAL, op. cit., p. 39.
} 
A partir da análise desta pequena descrição de viagem podemos discutir a dinâmica da situação de trabalho, no que tange as relações comercias postas em prática. Estamos diante de negociações econômicas realizadas pelos "ribeirinhos", com base em moeda estrangeira, já que a galinha comprada pelo viajante foi paga em dólares. É-nos revelado, porém, que esta pequena venda de animais domésticos se dava se forma esporádica. O viajante chegou até o "rancho", notou a presença de galinhas e ofereceu dinheiro para a sua compra, o "bom humorado velhinho" então aceitou a oferta. Isto é, não se constituía como atividade regular, por outro lado, ela se apresentava como uma possibilidade compensatória que se concretizava quando um visitante fazia uma proposta tão sedutora e lucrativa.

Outro aspecto que podemos desvendar é a importância das pequenas propriedades para os percursos e passeios fluviais no Pantanal, pois ao longo dos rios havia algumas paragens bem específicas nos denominados "ranchos", mais utilizados pelas embarcações de pequeno porte. Transportado por uma lancha, isto é, por uma pequena embarcação, não devemos ignorar por parte do estrangeiro Mulhal, o valor atribuído as propriedades menores para a própria continuidade e garantia da sua viagem ${ }^{37}$. Sendo assim, o "rancho" tinha uma função significativa voltada tanto para o abastecimento das embarcações - corte de madeira, como fonte de combustível quanto para o abastecimento dos tripulantes - seja de produtos caseiros ou da venda de animais domésticos.

Entre as atividades até então citadas, nota-se que a retirada de lenha foi uma das práticas mais significativas para a via fluvial e que visivelmente alterou a paisagem pantaneira. Todavia, entre os aspectos relevantes em relação ao corte de árvores, destacam-se as novas relações de troca e comércio acionada nos portos, engendrando valores inerentes a um mercado mais amplo ao mesmo tempo em que atualizava as relações dos moradores locais com a sociedade.

Isso fica mais nítido quando passamos a desvendar as condições materiais em sentido contrário, através das novas necessidades internas que passaram a surgir a partir de então. Pois, se atentando a troca e a venda deve-se ressaltar que a comercialização também operava para atender as exigências dos moradores rurais. Muitas dessas comunidades locais trocavam ou vendiam peles e couros "suprindo

\footnotetext{
${ }^{37}$ Há de se ressaltar que mesmo entre as embarcações maiores, as pequenas propriedades continuavam a ter um respaldo fluvial, pois as chatas que acompanhavam os barcos a vapores se locomoviam facilmente entre as áreas navegáveis mais estreitas a procura de propriedades menores que tivessem lenhas a disposição para a comercialização. As chatas, aliás, tinha grande serventia, sobretudo, perante seu fácil deslocamento entre os trechos fluviais mais difíceis.
} 
desta forma necessidades de artigos que não tinham condições de produzir, como por exemplo, o sal e utensílios de ferro" ${ }^{\prime 38}$. Isto é, produtos oriundos de outras regiões também supriam as "carências" alimentícias e materiais dos moradores pantaneiros, em que Corrêa Filho descreve que,

\begin{abstract}
Processava-se ronceiramente a ocupação efetiva dos pantanais, quando a abertura do rio Paraguai ao trânsito dos navios brasileiros apressou-lhe o ritmo da utilização. Aumentaram em número as moradias ribeirinhas, com que já dispunham de meio seguro de ligações periódicas, tanto com o capital, como para baixo, até algum porto litorâneo. Estreitaram-se as relações mercantis com a Praça Montevidéu, para onde eram enviados os couros de gado vacum, solas, além de produtos destinados ao consumo de laboratório europeus, como a ipecacuanha. Em sentido contrário, carregava os navios, para o consumo regional, farinha de trigo, azeite-doce, vinho, sabão e até açúcar branco. Neste particular, a possibilidade, proporcionada pela navegação de transporte dos maquinismos, que de outro modo seria inexeqüível, animou os empreendedores a encetar a indústria açucareira em proporções avantajadas. ${ }^{39}$
\end{abstract}

Outra atividade que se destacava, ainda neste ramo, era a pesca que adquiria uma dimensão cada vez maior entre os agricultores livres da beira dos rios. Como bem observa D'Alincourt :

Parte dos produtos da pescaria era utilizada para a fabricação de azeite, consumido na alimentação e como fonte de iluminação. No século XIX, o azeite de peixe, junto com a de mamona, figurava na relação dos produtos comercializados nos mercados públicos de Cuiabá e constituía um importante recurso econômico da população ribeirinha. Costumava-se também secar o peixe ao sol para conservá-lo por mais tempo. ${ }^{40}$

O óleo do peixe era feito da seguinte forma pelos "ribeirinhos", de acordo com o Presidente da Província de Mato Grosso,

\begin{abstract}
No tempo da baixa do rio, que é quando se aplicam a tal serviço, a margem de uma ou outra praia, põem em um tacho a ferver com água e a proporção que a gordura sobrenada, apanham-na em potes. Assim se fabrica o azeite. De todos os peixes que produz o rio, o lambari é o que dá melhor e mais claro azeite. Este peixe é menor que uma sardinha e pescam-no ou na beira do rio, onde ele se aglomera, com uma peneira, ou em canoa com um tacho. Batendo na horda da canoa, o peixe salta dentro dela. ${ }^{41}$
\end{abstract}

O azeite do peixe era importante para a população da província, uma vez que era responsável pela iluminação pública que era feita por lampiões, desde 1839, na

\footnotetext{
${ }^{38}$ CASTRO, M. I. \& GALETTI, L. G., op. cit., p. 17.

${ }^{39}$ CORRÊA, V. C., op. cit., p. 104.

40 D`ALINCOURT apud CASTRO, M. I. \& GALETTI, L. G.; op, cit. p. 17

${ }^{41}$ Relatório de presidente da província de Mato Grosso, apresentado a Assembléia Legislativa, pelo Exm. Sr. tenente coronel Francisco José Cardozo Junior, no dia 4 de outubro de 1872, p. 112.
} 
capital. "Esta fraca iluminação era complementada por outros lampiões e candeeiros colocados pelos moradores nas portas de suas casas". Corrêa Filho acrescenta que "mesmo após a introdução do querosene como combustível na iluminação pública, em 1874 , as populações pobres continuaram a usar o óleo do peixe ou mamona em seus lampiões, especialmente a área rural” ${ }^{42}$. Em 1873, o presidente da província Francisco José Cardoso Junior pedia a substituição do óleo de peixe, pelo querosene:

Também muito se recente esta capital pela falta de iluminação em suas ruas, durante as noites escuras. Os fundos que se acham consignados para tal fim, são diminutos para as exigências de um serviço que, ainda em pequena escala, entendo que deve ser feita mediante o emprego, como combustível, querosene, do em substituição ao azeite de peixe que não garante uma luz estável, intensa e pura ${ }^{43}$.

A importância do azeite do peixe se estendia, especialmente, a sua utilidade doméstica, porque poderia ele substituir o óleo na cozinha e, em alguns casos, ser utilizado na feitura de repelentes. Entretanto, o que mais marcava este produto era seu uso nas propriedades existentes ao longo dos rios Cuiabá e São Lourenço, perante o aumento do número de residências a partir de 1870. Aos poucos o azeite do peixe ampliou-se bastante em virtude da abundância de recursos naturais e a forma como eram produzidos. Corrêa Filho descreve que:

Ao declinar das águas, aumenta o número de espécies de escamas, cuja abundância gerou a indústria fácil de azeite de peixe, especialmente no município de Santo Antônio, em cujos limites finalizam os pantanais, a nordeste. As praias extensas, suavemente inclinadas, recolhem-se as redes, que distendidas com perícia, cercam numerosos grupos de lambari, piquiras e seus perseguidores de maior porte, entre os quais sobreleva o dourado ${ }^{44}$.

O óleo do peixe abastecia não só o meio urbano, ou as pequenas e médias propriedades rurais, mas sobretudo, as fazendas de gado e usinas do Pantanal - nas moradias oferecidas para as famílias contratadas.

Sendo assim, os "ribeirinhos" tinham na prática da pesca um leque de opções não só relacionadas à alimentação destes animais capturados, mas também aos diversos produtos que tirados do peixe poderiam ser comercializados ou trocados localmente. Sobre o óleo de peixe Corrêa Filho afirma:

De caráter doméstico, sem dúvida. Não obstante desprovida de melhores cuidados para o afinamento do produto e diminuição de desperdícios,

\footnotetext{
${ }^{43}$ Relatório de presidente da província de Mato Grosso, apresentado a Assembléia Legislativa, pelo Exm. Sr. tenente coronel Francisco José Cardozo Junior, no dia 4 de outubro de 1872, p. 92.

${ }^{44}$ CORRÊA FILHO, V. C., op. cit., p. 74-75.
} 
contribui para a manutenção de muitas famílias ribeirinhas, a quem proporciona meios de troca, por outras utilidades, de que hão mister, além de fornecer lubrificante de uso generalizado nos estabelecimentos rurais dos municípios vizinhos. A época da fabricação coincide com a das lufadas [...] que em Cuiabá e Rio-Abaixo corresponde à piracema indígena, para denominar a migração de milhares de peixes, buliçosos e fácil de pegar, para consumo culinário e industrial ${ }^{45}$.

O que estamos vendo até aqui são os comportamentos diversificados dos "ribeirinhos", em decorrência do fim da guerra com o Paraguai e a inserção das embarcações a vapores. Esses acontecimentos proporcionaram entre os moradores da beira do rio São Lourenço e Cuiabá, a emergência de novas relações de troca e comércio que consistiram, por sua vez, na intensificação de atividades específicas vinculadas a utilização dos recursos naturais para um alcance maior de excedentes. A caça, a pesca, a retirada de lenhas, a produção industrial caseira, assim como a criação de animais domésticos, somente nos apontam o quanto as atividades cotidianas dos "ribeirinhos" eram variadas e variáveis.

Já em relação aos agregados, que possuíam relativa autonomia se comparados com os escravos e mesmo com os camaradas Corrêa Filho aponta que:

Isentos de obrigação contínua, poderão aplicar a sua atividade como the aprouver, inclusive de maneira que obtenham produtos de plantações reduzidas ou de indústrias domésticas, de valor comercial, como artefatos de correia, de sola, pele de animais caçados, cuja compra toca a preferência de seu chefe ${ }^{46}$

Contudo, há de se notar que estes trabalhadores ao desenvolverem outras atividades rurais, como as mencionadas acima, beneficiavam muito mais seus patrões que a si mesmos. O simples fato dos grandes proprietários terem preferência na comercialização da indústria caseira já nos aponta a importância dessa produção rural e, possivelmente familiar, em pequena e média escala. Isto pode ser explicado com base em uma economia monetária que foi pouco a pouco se desenvolvendo, sobretudo, nas fazendas, usinas e engenhos do Pantanal. Pois, estes produtos oriundos das atividades familiares realizado nas grandes propriedades, eram comercializados, posteriormente - como já salientamos - com as embarcações a vapores durante as paragens nos portos.

Nesse sentido, estas porções de terras cedidas para os agregados, assim como a autonomia individual de caráter flexível, com certa "frouxidão", para a realização de outras práticas - a exemplo da caça, da agricultura e da criação de animais significavam muito mais um trabalho extra-econômico, dos quais os grandes

${ }^{45}$ CORRÊA FILHO, V. C., op. cit., p. 75.

${ }^{46}$ Idem, ibidem, p. 122. 
proprietários tiravam os maiores lucros. Percebe-se que a lógica tradicional rural e local, pelo menos em Mato Grosso, na extensa área úmida, se metamorfoseou até certo ponto em decorrência da expansão do mercado. Que não ocasionou, no entanto, rupturas no que concerne às relações e organizações espaciais internas.

Sobre isso seria interessante trazermos à tona algumas considerações feitas por M. S. C. Franco, em suas análises realizadas á respeito da instalação da produção do café em São Paulo e o impacto desta atividade sobre a região do Vale do Paranaíba, no século XIX, em que a autora trata a maneira como essas negociações comerciais mais amplas puderam ser engendradas no seio de uma economia rural e tradicional, em que seus moradores tinham uma vida agrária pouco ligada a um capitalismo industrial mais maduro. Franco chama a atenção para certo grau de incoerência presente durante todo esse processo. Segundo a mesma:

convém lembrar que a síntese das orientações contraditórias da vida econômica- produção para consumo direto e para mercado-, presentes nas grandes propriedades fundiárias, desenvolveu-se mediante o reforço e a expansão da atividade mercantil ${ }^{47}$.

Feito estas observações podemos destacar que no Pantanal, a expansão mercantil que atingiu as grandes propriedades se utilizou de um dispositivo bastante eficaz para aquele momento, isto é, se recorreram aos padrões costumeiros de um ambiente rural para se inserirem em uma economia "moderna"- o capitalismo industrial. Foi isso que aconteceu, por exemplo, entre os agregados, que aumentaram sua produção caseira e familiar para atenderem um mercado que crescia gradativamente.

Vimos até aqui, os beneficiamentos das atividades rurais extras ofertadas pelos agregados em relação ao seu "senhor". Contudo, a intensificação de uma produção industrial doméstica proporcionou aos agregados um pequeno lucro adicional para sua família, pois, nesse momento a exploração ambiental desencadeou uma especialização interna de atividades - como a pesca, a retirada de lenhas e outros, como já foi dito que visassem tão somente utilização dos recursos naturais ${ }^{48}$.

Todavia, isto não foi o suficiente para fragmentar ou desconfigurar as relações de "confiança" e "fidelidade" desenvolvidas entre os agregados e seu "senhor". Se por um lado o aumento da exploração dos recursos naturais ofertou a sua inclusão como matérias-primas num mercado em expansão, por outro lado estreitou as relações de

\footnotetext{
${ }^{47}$ FRANCO, M. S. C., “Homens livres na ordem escravocrata”. São Paulo: Fundação Editora UNESP, (Biblioteca básica ), 4으., 1997, p. 170.

${ }^{48}$ Esse fato pode ser vislumbrado nos relatos de viagem como foi o caso de Proença, viajante que esteve em Mato grosso e ao percorrer o Pantanal Norte mostrou-se surpreso com a quantidade de caça desenvolvida internamente entre os camaradas, realizadas inclusive em turmas PROENÇA, op. cit., p.53.
} 
troca e comércio entre os proprietários e seus empregados "livres", isto é, aumentou a dependência mútua entre ambos.

Seria inútil qualquer tentativa que viesse a aprofundar as novas lógicas e relações comerciais e de troca nas grandes propriedades no Pantanal, mesmo porque este não é o nosso foco de pesquisa, sem contar que deveríamos fazer toda uma análise em torno dos dispositivos que regiam as negociações internas e atravessavam os códigos locais, estamos falando aqui do "clientelismo", do "patriarcalismo" e do "compadrio" que por si só são elementos muito complexos. O que pretendemos mostrar é que a inserção dos recursos naturais no Pantanal num mercado amplo não impediu a reprodução de uma economia tradicional.

No que toca os "ribeirinhos" realmente, a atualização do cotidiano dos "ribeirinhos" só foi possível graças à articulação ao capitalismo industrial. Contudo, o engendramento dessas novas relações não implicou entre estes moradores rurais a imposição de regras, valores e da disciplina do trabalho industrial intrínseco a esse sistema. De fato, isso decorreu devido ao seu pouco efeito sobre o "tempo da natureza" que continuou a ser engendrado entre os moradores da beira do rio.

Para os "ribeirinhos" essa indiferença do tempo enquanto moeda reflete o pouco apego entre estes moradores locais a noção de acúmulo de capital e bens materiais e, conseqüentemente, do papel diminuto que o relógio ocupava no cerne das tarefas diárias. Como salienta Thompson:

\begin{abstract}
Sem dúvida, esse descaso pelo tempo do relógio só é possível numa comunidade de pequenos agricultores e pescadores, cuja estrutura de mercado e administração é mínima, e na qual as tarefas diárias (que podem variar da pesca ao plantio, construção de casas, remendo de redes, feitura dos telhados, de um berço ou de um caixão) parecem se desenrolar pela lógica da necessidade, diante dos olhos do pequeno lavrador. Mas a descrição de Synge serve para enfatizar o condicionamento essencial em diferentes notações de tempo geradas por diferentes situações de trabalho, e sua relação com os ritmos "naturais". ${ }^{49}$
\end{abstract}

Thompson nos chama a atenção para a importância das condições e da disponibilidade dos recursos naturais, pois, estes são um dos fatores que permitem a variação das atividades desencadeadas diariamente. O que mais nos interessa neste trecho de sua reflexão, se refere à apatia sobre o relógio que não têm uma funcionalidade para a reprodução dessa ruralidade. O tempo permanece sendo marcado pelas tarefas. Assim, eram as práticas que norteavam a ocupação do tempo cotidiano, operando nas trocas de experiências e nas espacializações locais. Entre os "ribeirinhos" transcorria o "tempo da caça", o "tempo da pesca", o "tempo da roça", o

\footnotetext{
${ }^{49}$ THOMPSON, E. P., op. cit., p. 271.
} 
"tempo da retirada de lenhas", o "tempo da produção caseira", o "tempo da criação de gado", permitindo a intensificação ou não dessas práticas em determinadas épocas do ano, enfim, o "tempo natural" agregou novos valores e relações sociais e econômicas, mas não perdeu seu lugar no cotidiano.

\section{A INTENSIFICAÇÃO DO COMÉRCIO EM PEQUENA ESCALA}

O comércio e as trocas intensificadas ao longo da região pesquisada, a partir de 1870, seja ela realizada com o mercado local ou com o mercado internacional, em pequena ou em grande escala, não se restringiam as embarcações a vapor. Os mascates também estavam presentes nas negociações realizadas no extenso Pantanal Norte. Segundo Corrêa, estes comerciantes eram importantes também para a comercialização das usinas de açúcar:

Do canavial às moendas, como das matas as fornalhas, sucedem-se, pejodos
de feixes de cana ou de lenha, veículos vários, desde carro de boi, ao
Decauville, usado em mais de um estabelecimento, quando não seja possível
a utilização da via fluvial, pela qual se escoa toda a produção. Nessa quadra,
enxameia o rio Cuiabá de embarcações, que vão levar as usinas os artigos de
importação e buscar o açúcar produzido para oferecê-lo aos consumidores.
Chatas, o reboque de lanchas, ou tocada por zingueiros, barcos
habitualmente utilizados pelos mascates, batelões e remos, de reduzida
capacidade, tudo se mobiliza para o transporte de sacas de açúcar e
garrafões ou pipas de álcool e aguardente, comprobatórios das atividades
usineiras, desenvolvidas em pleno pantanal, que rodeia o engenho das
Flechas, na ilha do Piraim, e se abeira, em faixa variável, de outros, cujo
terreno, pelo interior, a espaços empolados, já se alteia nas escassas
ramificações montuosas, de contrafortes ligados ao divisor de águas
tributárias de Cuiabá e do Paraguai. Diferenciador de usinas, que se
contentavam, a orla dos pantanais, com área territorial apoucada em
relação ao prestigio do seu proprietário, decorrente da organização
industrial, as fazendas pastoris dilatavam-se desmedidamente, para que
fosse compensadora a criação pelos processos usuais. 50

É impossível buscar entender o engendramento das novas relações de venda e troca dos "ribeirinhos" em questão, sem nos enveredar aos caminhos traçados pelos mascates tendo em mente a importância das atividades que eles reproduziam. Os serviços prestados por estes comerciantes eram, em grande parte, os que não poderiam ser realizados por escravos, empregados contratados das grandes propriedades e homens com muitas posses. As embarcações para o mascate tinham um sentido diferenciado, já que exerciam uma dupla função que ia desde um lugar de trabalho até um ambiente de estadia ao longo de seu trajeto diário. Segundo Steinen:

${ }^{50}$ CORRÊA, V. C., op. cit., p. 109-110. 
Uma espécie de barco primitivo se achava na margem do rio. Numa das extremidades dessa embarcação, uma mulher preparava o almoço num fogão pequenino. A tripulação veio tida para a terra. O barco era uma espécie de armazém flutuante, do tipo desses que sobem e descem os rios carregados de toda sorte de mercadoria e que atracam onde quer que haja habitações. São as únicas lojas que muitos habitantes daquela paragem avistam durante o rio. Eles navegam bem pelo rio abaixo, porém, rio acima são empurrados a zingas pela tripulação, quando não conseguem, o que não é sempre, ser levados a reboque por algum vapor. $O$ de que falamos tinha um pequeno cômodo coberto de zinco; outros o têm com o teto de sapé ou de couro. O rio descia em curvas pelo vasto pantanal de que se separava apenas por uma franja de matas. ${ }^{51}$

Descendo e subindo o rio, dormindo em pleno percurso à luz das estrelas ou nas paragens realizadas nas propriedades, estes negociantes atendiam a um público variado, indo desde pequenos agricultores a grandes fazendeiros e usineiros. Percorrendo cidades e ambientes rurais, se atracando em lugares mais distantes aonde as embarcações a vapor provavelmente jamais iriam, em virtude das condições ambientais, os mascates eram profundos conhecedores da região pantaneira.

Entre seus aspectos mais relevantes encontrava-se o fato de que o ciclo de sua atividade, enquanto comerciante, nunca se esgotava. 0 mascate não realizava apenas a venda, mas suas relações se estendiam também para as trocas, isto é, se desdobravam para relações de contraprestação comercial. A cada visita que realizava entre as moradias na extensa área alagável poderia desenvolver a função de abastecedor das famílias locais ou em contrapartida, ser abastecido, já que este negociante entregava mercadorias assim como buscava outras. Os estoques de seus produtos eram constantemente refeitos e suas atividades reiniciadas. A lógica do seu trabalho girava em torno de lucro gerado em negociações que não preconizava, exclusivamente, a circulação monetária, mas também de mercadorias.

Nesse sentido seria interessante ter a noção de alguns produtos que estes comerciantes transportavam. Para tanto, vejamos um pequeno trecho de um comentário feito pelo pesquisador mato-grossense A. de Azevedo, que nos trás alguns detalhes:

[...] A segunda categoria de transporte comercial, incumbiu-se do movimento interno, feito de porto a porto, de lugarejo a lugarejo. Conduz também, sem dúvida, mercadorias de outras regiões, sobretudo produtos importados de São Paulo ou via São Paulo, para a mercancia com a população beira-rio a quem supre de artigos de armarinho, os tecidos, os medicamentos, as linhas, os anzóis e tantos outros. A lancha funcionando como um estabelecimento varejista, ambulante, tem ainda a função de receber para conduzir a outras regiões, ou para revenda nas margens do Cuiabá, aqueles produtos de que dispõem os habitantes da beira-rio como

\footnotetext{
${ }^{51}$ STEINEN, K. v. de, op. cit., p. 77.
} 
fumo em corda o arroz, e as peles. É o comércio ribeirinho do "regatão", com suas feições peculiares. Dada a circunstancia de transportar aquelas mercadorias pertencentes à empresa e para seu próprio negócio, a firma que faz esse comércio é muito menos prejudicada pela concorrência do transporte rodoviário. ${ }^{52}$

Mesmo que este pequeno trecho, tenha sido feito em um período posterior a qual estamos tratando, cremos que suas informações se aproxima das que são oferecidas por outro estudioso inserido no recorte temporal em questão - V. Corrêa Filho. Nesse sentido, as obras de ambos os autores são trabalhadas neste artigo como documentos e não apenas bibliografia. Reiterando que Azevedo desenvolveu estudos na área da geografia humana, dos quais deu grande atenção a venda e troca desenvolvidas por pequenos comerciantes que perambulavam pelas ruas de Cuiabá ${ }^{53}$.

O arroz, o fumo são alguns dos produtos agrícolas citados por Azevedo, que em contrapartida menciona os produtos consumidos internamente, como os "artigos de armarinho, os tecidos, os medicamentos, as linhas, os anzóis e tantos outros". Segundo o autor o mais surpreendente entre estes trabalhadores, os mascates, era a sua importância para as negociações voltadas ao mercado estrangeiro. Vejamos algumas de suas observações à esse respeito:

Neste intercâmbio de longo percurso sobem o Cuiabá com produtos como a
farinha de trigo, o sal, a querosene, a gasolina, as ferragens, a farinha de
mandioca. Exportam-se rio-abaixo, principalmente peles e couros de
animais selvagens como a lontra, a arranha, a jaguatirica e, em maior
volume a capivara. Exportam-se ainda crina animal e peles de garça. Certas
quantidades desses produtos não se detém no mercado interno brasileiro,
procurando antes,. Praças estrangeiras notadamente nos Estados Unidos. ${ }^{54}$

Notemos que parte dos produtos citados se refere à caça, ou seja, a recursos naturais que eram, em sua maioria, exportados. É neste ponto que podemos perceber a singularidade destes comerciantes, cujas atividades reuniam duas

\footnotetext{
${ }^{52}$ AZEVEDO, A. de, "Cuiabá: estudo de Geografia Humana". Anais da Associação dos Geógrafos Brasileiros, VII (II), 1952-1953. São Paulo, 1957, p. 246

${ }^{53}$ Outra obra que poderia ser citada no que diga respeito ao pequeno comércio cuiabano seria: AZEVEDO, A. de, "Cuiabá: estudo de Geografia Humana." Relatório apresentado por Aroldo de Azevedo orientador geral de pesquisa de campo, Julho de 1953. Sobre este estudioso seria interessante fazermos algumas observações. As pesquisas de Azevedo foram realizadas, sobretudo, nas décadas de 1940 e 1950, momento em que the chamou bastante atenção as atividades e as trocas de experiências desenvolvidas pelos mascates. Para fazer suas análises, utilizou como método as pesquisas de campo de cunho etnográfico, período em que se dedicou bastante a viagens locais. Como resultado publicou o livro supracitado, obra esta que deu atenção significativa ao mercado fluvial e as funções dos mascates, que tinham um papel fundamental em negociações que atendiam as moradias da beira do rio, especialmente, os agricultores livres, também identificados como "ribeirinhos". Isto é, além das relações mercantis ou não, realizadas nas grandes propriedades, especialmente nas usinas de açúcar, os moradores dos "ranchos" também eram um dos públicos atendidos pelos mascates.

${ }^{54}$ AZEVEDO, A. de, op. cit., p. 245.
} 
características extremamente importantes nas novas relações comercias que estavam sendo engendradas junto aos moradores da área alagável: uma tecnologia "rudimentar" ligada, simultaneamente, a um empreendimento mercantil que atendia a indústria estrangeira.

Isto nos leva a refletir sobre outro ponto, pois suas trocas de experiência conseguiam ligar a cidade ao campo e, por conseguinte, o campo ao mercado estrangeiro. Os mascates, portanto, tinha como uma de suas funções fazer do rio e de sua prática diária uma ponte, uma comunicação dos moradores locais com o mercado mundial. Servia como intermediário comercial, social e cultural das famílias pantaneiras com as grandes potências econômicas daquele momento, já que forneciam e traziam mercadorias de outros países, e da capital de Mato Grosso.

Em muitos casos, os "ribeirinhos" viam nas transações com os mascates o único meio de desenvolverem negociações das mercadorias produzidas localmente. A dificuldade com a distância, o dispêndio do tempo de locomoção até outra localidade, a dívida dos favores prestados pelos grandes proprietários, seriam problemas sanados em virtude da presença dos mascates no Pantanal. A lógica que guiava os comportamentos dos mascates também merece atenção. As atitudes, a moralidade, as idéias que permeavam o convívio destes comerciantes com os moradores pantaneiros, nos possibilita visualizar os artifícios empreendidos na dinâmica de seu trabalho. $A$ análise de M. S. de C. Franco sobre a relação entre comerciantes, vendeiros ${ }^{55} \mathrm{e}$ tropeiros ${ }^{56}$ e dos diferentes "estratos" sociais na região do Vale do Paranayba, em São Paulo, nas últimas décadas do século XIX, contribui para a compreensão desta lógica. De acordo com a autora:

Em resumo, a posição do vendeiro, incerta e oscilante, se localiza nos intervalos dos grupos componentes do sistema social. Sua atividade transcorria na intersecção dos planos em que se desdobrava a economia - o mercantil e a subsistência. Seu comportamento reúne características tanto dos estratos superiores, com a exploração hábil dos esquemas de dominação, quanto das camadas pobres, participando de sua moralidade. Estas condições de sua existência foram sintetizadas na técnica competitiva que foi sua, por excelência: a astúcia e a malícia para criar e exaurir as oportunidades de formar pecúlio num em que o dinheiro era escasso. ${ }^{57}$

Franco destaca em sua análise os ambientes percorridos por este trabalhador e os valores acionados diante das relações prestadas no corrente do seu dia. O vendeiro, provindo de meio rural "pobre"- de acordo com a cultura européia-, com sua moralidade popular estabelecia trocas de experiências econômicas com

\footnotetext{
${ }^{55}$ Trabalhador responsável pelos armazéns presentes nas grandes propriedades rurais.

${ }^{56}$ FRANCO, M. S. C. de, op. cit., p. 65.

${ }^{57}$ Idem, ibidem, p. 83.
} 
grupos pertencentes a elite local que continham preceitos e ideias proeminentes. No entanto, isso só era possível diante das estratégias utilizadas por este comerciante, que giravam em torno da astúcia e da malícia. Sobre isso a autora tece maiores comentários:

[...] a posição oscilante e o comportamento dúbio do vendeiro representa mecanismos que garantem seu próprio equilíbrio na sociedade. A malandragem, a esperteza, o expediente consistem, para ele na forma possível de acomodação a uma ordem social em que sua atividade é marginal e quase dispensável. Este quase que falta para que ela inexista, não é suficiente, por outro lado, para dotar aquele que a exerce dentro de uma situação definida no mercado a uma correspondente situação social estável. ${ }^{58}$

Não apenas os vendeiros, mas os tropeiros também seguiram o mesmo caminho estratégico. Como bem analisa a socióloga, um componente significativo nas atividades realizadas entre estes- os tropeiros - se baseavam, entre outros fatores, nas investidas de novidadeiros os quais nem sempre eram dignos de "confiança". A esperteza, presente em suas relações aponta a astúcia, que estes comerciantes deveriam ter como atributo para conseguir traçar negociações entre moradores de tão distintos ambientes - cidade e campo - e cultura, já que a clientela possuía distinta condição financeira e valores em relação aos comerciantes.

Contudo, de acordo com citação acima, o aspecto diferencial que Franco nos leva a pensar sobre os vendeiros diz respeito a uma característica presente nas suas transações: a posição econômica de sua atividade. A autora destaca que a dinâmica dos serviços prestados por estes, estavam associados a uma ação marginal. Se pegarmos o caso dos mascates veremos que suas práticas não estavam muito longe dessa condição social. Os mascates não são encontrados nos documentos oficiais que continham os quadros de pagamentos de impostos sobre os produtos importados e exportados de Mato Grosso. Suas negociações não são citadas, também, nos documentos alfandegários ${ }^{59}$.

Dessa forma, o que a ação destes pequenos comerciantes - os mascates - nos revela é a reprodução de relações sociais e econômicas que escapavam de um controle oficial e da elite local. Oficial, porque estas embarcações de pequeno porte, que trafegavam pelos rios, não estavam inseridas entre as transportes fluviais legalizados que tinham total liberação dos governantes províncias ou estaduais para viajarem. Apesar de desenvolverem negociações com os fazendeiros, usineiras e donos de

\footnotetext{
58 Idem, ibidem, p. 80.

${ }^{59}$ Somente as embarcações pertencentes a firmas.
} 
engenhos, suas transações comerciais tinham um caráter autônomo, que estava longe de representar laços de dependência como os camaradas, por exemplo.

Tendo isso em mente, seria interessante enfatizarmos que possivelmente a viabilidade dos mascates se inserirem em um mercado estrangeiro esteja ligada a sua descendência e situação social e financeira. Grande parte dos mascates que trafegavam pelo Pantanal Norte era constituída por imigrantes variados como turcos, árabes, entre outros ${ }^{60}$; que venderam tudo que tinham em seus países de origem e vieram em busca de seus sonhos. Estes estrangeiros que se instalaram em Cuiabá e Corumbá queriam alcançar uma ascensão financeira, uma condição social mais favorável ${ }^{61}$. Com isso se enveredaram pelos meandros de um comércio alternativo e não oficial. Solução esta encontrada para fugirem dos altos impostos cobrados sobre os produtos e matérias-primas exportadas pelo porto de Corumbá e, por conseguinte, a segurança ou garantia de um retorno mais rápido e lucrativo sobre seus negócios.

Nesse sentido, devemos levar em consideração a viabilidade da mobilidade social que esta prática permitia aos mascates, ao extrapolarem as transações comerciais, feito pelo caminho fluvial e previsto pelas condutas legais. As atividades dos mascates sinalizam uma estratégia, um mecanismo encontrado para quebrar a rigidez que o sistema social impunha entre os trabalhadores rurais menos favorecidos economicamente. E mais, a forte presença desses comerciantes informais no território alagável nos deixa bem claro que as negociações internas, desenvolvidas com os "ribeirinhos" não se davam apenas de forma direta com as embarcações fluviais, ou indiretas por meio dos grandes fazendeiros, mas sim que havia outro caminho para a troca de mercadorias e experiências entre os moradores da beira do rio e os comerciantes de pequeno porte.

Sendo assim neste artigo, é possível perceber por parte dos "ribeirinhos" não apenas a intensificação das relações de troca e comércio com as embarcações fluviais no período pós-guerra com o Paraguai (1870). Mas, especialmente, como os moradores da beira dos rios da região norte pantaneira exteriorizavam as transformações mais ampla que atingiram Mato Grosso no período em questão. A reabertura fluvial no ano de 1870, a intensificação da utilização do barco a vapor, o aumento da exploração e comercialização dos recursos disponíveis, o fim da escravidão, a solidificação de uma elite local que adquiriu maior força com o advento da República no Brasil. O nosso interesse era analisar como esse conjunto de

\footnotetext{
${ }^{60}$ BRANDÃO, J. da S., “A história da navegação em Mato Grosso” Ed. Livro mato-grossense, 1991, p.5759.
} 
acontecimentos atingiu e modificou o dia-a-dia dos "ribeirinhos". E neste contexto o que se percebe é que esses moradores locais reproduziram uma racionalidade interna frente às pressões externas - no que tange a sua inserção em um mercado em expansão - que os permitiam atualizar seu cotidiano sem se desvincular de sua temporalidade específica, apresentando uma característica que Thompson define como "resistência teimosa" ${ }^{62}$. Dessa maneira procuramos falar - neste artigo - sobre o "tempo da natureza" dos "ribeirinhos", de um tempo lento, contínuo e relativamente independente que entrava em choque de forma visível e invisível com um "tempo moderno", veloz e padronizado que era o praticado nas grandes propriedades do Pantanal Norte.

${ }^{62}$ Cf: THOMPSON, E. P., op. cit. 